Original Research Paper

\title{
Penerapan Teknik Flushing untuk Memacu Produksi Peternakan Kambing Perbibitan di Kabupaten Lombok Utara
}

\author{
Rr. Agustien Suhardiani ${ }^{1}$, L. Wirapribadi ${ }^{1 *}$, Happy Poerwoto ${ }^{1}$, M. Ashari ${ }^{1}$, Rina Andriati ${ }^{1}$, Tahyah Hidjaz ${ }^{1}$ \\ ${ }^{1}$ Laboratorium Ternak Potong dan Kerja Fakultas Peternakan, Universitas Mataram, Mataram, Indonesia;
}

https://doi.org/10.29303/jpmpi.v3i2.1101

Sitasi: Suhardiani, Rr, A., Wirapribadi, L., Poerwoto, H., Ashari, M., Andriati, R \& Hidjaz, T. (2021 Penerapan Teknik Flushing untuk Memacu Produksi Peternakan Kambing Perbibitan di Kabupaten Lombok Utara. Jurnal Pengabdian Magister Pendidikan IPA 4(4)

\section{Article history}

Received: 02 Oktober 2021

Revised: 20 Oktober 2021

Accepted: 04 November 2021

*Corresponding Author: L. Wirapribadi, Laboratorium Ternak Potong dan Kerja Fakultas Peternakan,

Universitas Mataram, Mataram, Indonesia;

Email:

wirapribadi19@gmail.com

\begin{abstract}
Suatu kegiatan pengabdian kepada masyarakat dengan tujuan pokok untuk memacu produksi peternakan kambing perbibitan di Kabupaten Lombok Utara, Provinsi Nusa Tenggara Barat, dilaksanakan dalam bentuk penyuluhan dengan metode demplot, orasi, dan diseminasi Ipteks melalui penyebaran leaflet. Kegiatan berlokasi di Desa Rempek dan Ganggelang Kecamatan Gangga, dengan sasaran strategis para peternak pada dua kelompok peternakan kambing perbibitan, dari kedua kelompok diambil 20 peternak sebagai sasaran langsung pembinaan. Demplot dilakukan menggunakan 20 ekor kambing induk Peranakan Etawa(PE) umur 2,0-2,5 tahun dengan BCS rata-rata 4. Budidaya kambing perbibitan dengan aplikasi teknik flushing menggunakan formula pakan konsentrat berbasis tepung daun turi (Sesbania grandiflora) didemonstrasikan pada dua plot dengan pemberian pakan (hijauan + konsentrat flusher) sepenuhnya di dalam kandang selama 90 hari. Capaian tujuan dan manfaat kegiatan yang dievaluasi dengan metode survey menggunakan kuesioner dan pengukuran langsung kinerja reproduksi kambing-kambing demplot menunjukkan, semua peternak dari kedua kelompok sasaran telah memahami dengan baik materi Ipteks yang disuluhkan dan dipandang telah mampu mengembangkan budidaya kambing perbibitan dengan penerapan teknik flushing. Penerapan teknik Flushing sangat bermanfaat dalam mengatasi rendahnya angka kid crop sebagai akibat rendahnya performa prolifikasi ternak kambing perbibitan yang dibudidayakan.
\end{abstract}

Keywords: Kambing Peranakan Etawa (PE), perbibitan, flushing, kid crop, demplot.

\section{Pendahuluan}

Ternak kambing diketahui memiliki peran sangat penting bagi kehidupan sebagian penduduk Indonesia. Pemeliharaannya banyak dilakukan masyarakat di daerah pedesaan sebagai usaha sambilan untuk membantu menambah penghasilan keluarga. Hal ini dikarenakan pemeliharaan kambing relatif mudah, membutuhkan modal dan resiko kecil, perputaran modalnya relatif cepat karena ternak kambing bersifat prolifik dan interval kelahiran pendek, dapat dijual setiap saat, dapat memanfaatkan hijauan berkualitas rendah, daya adaptasinya tinggi, mempunyai fungsi ganda yaitu sebagai penghasil daging, kulit, tulang, pupuk maupun sebagai tabungan keluarga (Yamin et al., 2021).

Kambing yang banyak dipelihara masyarakat di Indonesia, diantaranya, adalah kambing Peranakan Etawah (PE). Kambing PE merupakan jenis kambing hasil persilangan antara kambing Kacang (kambing asli Indonesia) dengan kambing Etawa (jenis kambing India). Jenis kambing ini, baik jantan maupun betina, menunjukkan penampilan yang menarik dan 
merupakan penghasil daging dan susu yang cukup baik, lebih baik dari hasil daging maupun susu kambing lokal seperti kambing Kacang (Rozani et al., 2021). Oleh karena itu, Sarwono (1995) menyebutkan, jenis kambing ini sangat digemari oleh masyarakat sehingga penyebaran populasinya menjangkau hampir seluruh daerah di Indonesia. Saat ini sebagian besar kambing yang ada di Indonesia merupakan kambing hasil silang yang dikenal dengan kambing Peranakan Etawah (Djamal, 1998).

Salah satu daerah penyebaran kambing PE di Tanah Air adalah, Nusa Tenggara Barat (NTB). Di daerah ini kambing PE dapat dijumpai hingga di pelosok-pelosok dari kesepuluh wilayah kabupaten dan kota yang ada, dengan jumlah populasi diperkirakan mencapai 192.155 ekor atau 42,2\% dari total populasi kambing di NTB (Rahadi, 2015). Daerah kabupaten yang memiliki jumlah populasi kambing PE cukup besar, diantaranya adalah Kabupaten Lombok Utara sebanyak 20.092 ekor, dengan penyebaran populasi bervariasi pada 5 wilayah kecamatan yang ada. Konsentrasi kambing PE di Lombok Utara dijumpai tertinggi di Kecamatan Gangga, sebanyak 8.238 ekor (Zainuri et al, 2015).

Usaha produksi kambing PE di Kabupaten Lombok Utara sebagian besar merupakan usaha perbibitan, dalam hal ini, peternak memelihara induk-induk kambing muda umur 1-3 tahun yang kemudian dikawinkan dengan pejantan milik sendiri atau milik peternak lain, guna menghasilkan anak-anak kambing (cempe) yang selanjutnya dibesarkan beberapa bulan hingga menjadi kambing-kambing bibit atau bakalan yang siap dipasarkan. Usaha produksi demikian tampak cukup berkembang di kabupaten Lombok Utara, khususnya di Kecamatan Gangga. Dalam wilayah ini terdapat 23 kelompok usaha peternakan kambing, yang sebagian besar menekuni tipe produksi perbibitan (Pribadi et al, 2017).

Permasalahan yang dihadapi, meskipun penyebaran populasi kambing PE cukup meluas, kualitas sistem produksinya secara teknis dan manajemen tidak menunjukkan perkembangan yang signifikan. Sebagian besar $(88,4 \%)$ usaha perbibitan kambing PE di Lombok Utara masih bersifat tradisional (Pany, 2018), hanya mengandalkan potensi hijauan setempat sebagai input untuk proses produksi. Sementara hijauan lokal pada umumnya, kandungan nutrisinya relatif rendah karena umumnya kurang berdaun dan biasanya dipotong pada umur tua (Satoto,1994). Hal ini menyebabkan rendahnya capaian produksi anak (kid crop), dan waktu yang diperlukan (periode produksi) untuk mencapai standar bobot dan ukuran kambing bibit menjadi cukup panjang. Akibatnya, usaha produksi tersebut cenderung kurang efisien dan, kenyataannya pendapatan peternak menjadi relatif rendah. Laporan Zainuri et al (2015) menyebutkan, produksi anak (cempe) kambing PE yang diusahakan secara intensif tradisional di Lombok Utara hanya mencapai ratarata 1,43 ekor per kelahiran dan memerlukan waktu rata-rata 168 hari untuk mencapai bobot dan ukuran tubuh standar untuk bibit.

Mengingat bahwa sifat prolifik (kemampuan melahirkan anak kembar) merupakan sifat penting dalam produksi kambing bibit, maka upaya memacu sifat tersebut perlu menjadi perhatian dalam usaha perbibitan kambing PE. Upaya tersebut, menurut Blakely dan Bade (1988), dapat dilakukan dengan penerapan teknik flushing pada kambing betina (induk), yaitu dengan pemberian pakan ekstra tinggi protein (pada umumnya berupa biji-bijian) $2-3$ minggu sebelum ternak dikawinkan.

Penerapan teknik flushing untuk memacu kinerja sifat prolifik ternak diketahui cukup berkembang di negara-negara maju produsen ternak, dan paling populer terutama pada peternakan domba. Di Indonesia, karena sebagian besar usaha peternakan masih tradisional, penerapan teknik ini tidak berkembang bahkan kurang dikenal oleh peternak.

Uji Coba penerapan flushing menggunakan Premix-protein (formula pakan suplemen kualitas tinggi - hasil Litbang Iptek Nuklir Bidang Peternakan BATAN) pada induk kambing PE yang disilangkan dengan kambing Boer (Pribadi dan Rodiah, 2012), menghasilkan peningkatan kid crop sebesar 42,4\%. Hasil tersebut lebih tinggi dibanding penerapan flushing menggunakan jagung yang menghasilkan peningkatan kid crop sebesar 19,6\% (Heriadi $d k k .$, 1997), dan penggunaan gandum yang menghasilkan peningkatan kid crop 26,8\% (Nasution, 2001). Hal ini mendorong dilakukannya penerapan teknik flushing pada usaha perbibitan kambing PE yang semakin berkembang di Kabupaten Lombok Utara akhir-akhir ini. 


\section{Metode}

\section{Materi Kegiatan}

Penentuan materi kegiatan pengabdian kepada masyarakat ini didasarkan pada permasalahan yang dihadapi para peternak kambing perbibitan di Lombok Utara. Permasalahan utama yang dihadapi, adalah rendahnya kid crop akibat tidak optimalnya kinerja sifat prolifik kambing. Keadaan ini menyebabkan menjadi rendahnya efisiensi produksi perbibitan, sehingga pendapatan peternak menjadi rendah.

Keberlangsungan usaha perbibitan kambing PE secara tidak efisien tersebut tidak lepas dari kelemahan faktor manusia, dalam hal ini, adalah kurangnya pengetahuan dan keterampilan peternak mengenai manajemen (tatalaksana) usaha perbibitan, terutama manajemen dan teknik memacu kinerja sifat prolifik ternak. Sebagian besar $(88,4 \%)$ peternak perbibitan kambing PE di Lombok Utara masih tradisional dalam menjalankan usahanya, dalam hal ini, mereka hanya mengandalkan potensi pakan hijauan setempat sebagai input untuk proses produksi, sementara hijauan lokal pada umumnya, kandungan nutrisinya relatif rendah karena umumnya kurang berdaun dan biasanya dipotong pada umur tua. Hal ini menyebabkan rendahnya asupan nutrisi ternak, sehingga tidak mencukupi untuk meningkatkan jumlah ovum yang dapat dilepaskan dari ovarium pada saat ternak melangsungkan perkawinan guna terjadinya kelahiran kembar.

Sifat prolifik adalah sifat yang menunjukkan kemampuan ternak untuk melahirkan anak kembar (melahirkan anak lebih dari satu ekor dalam satu kelahiran). Kinerja sifat ini sangat dipengaruhi oleh taraf nutrisi (terutama protein) yang diperoleh ternak beberapa hari menjelang dikawinkan. Taraf nutrisi, dalam hal ini, berkaitan dengan jumlah ovum yang dapat terbentuk dan jumlah ovum tersebut yang dapat dilepaskan dari ovarium untuk dibuahi ; semakin baik taraf nutrisi yang diperoleh ternak beberapa hari sebelum dikawinkan, maka semakin banyak ovum yang dapat diproduksi di dalam ovarium, juga semakin banyak ovum tersebut yang dapat dilepaskan dari ovarium untuk dibuahi, sehingga semakin besar peluang untuk terjadinya kelahiran kembar. Semakin tinggi angka kelahiran kembar, maka semakin tinggi pula kid crop yang dihasilkan, sehingga produksi perbibitan dan pendapatan peternak akan meningkat.

Sehubungan dengan pentingnya taraf nutrisi terhadap sifat prolifik ternak, maka perlu diterapkan teknik flushing guna memacu kinerjanya. Teknik flushing adalah teknik pemberian pakan ekstra tinggi protein (biasanya berupa pakan biji-bijian seperti jagung, gandum, atau kacang-kacangan) kepada ternak betina (induk) beberapa hari sebelum ternak tersebut dikawinkan. Mengingat bahwa bahan pakan yang berupa biji-bijian belum lazim penggunaannya sebagai pakan ternak di kalangan peternakan kambing tradisional, maka untuk keperluan penerapan teknik flushing di kalangan usaha perbibitan kambing PE di Lombok Utara perlu dicari bahan pakan alternatif yang lebih lazim penggunaannya namun mengandung taraf nutrisi yang sebanding atau lebih tinggi daripada bijibijian tersebut. Dalam hal ini, telah dikembangkan suatu formula pakan konsentrat berbasis daun turi (Sesbania grandiflora), salah satu hasil rekayasa Litbang Ipteks Bidang Peternakan Pusat Studi Pembangunan (PSP-NTB, 2016). Bahan pakan ini merupakan formula padat protein, sehingga dipopulerkan dengan nama Promix Feed Supplement (PFS).

Penggunaan PFS sebagai pakan suplemen untuk ruminansia telah disosialisasikan secara luas pada kelompok-kelompok usaha ternak potong dan perbibitan di Pulau Lombok, terutama di kalangan peternakan sapi. Di Kabupaten Lombok Utara, penggunaan PFS telah dikembangkan pada peternakan sapi potong untuk mendukung Program Percepatan Swasembada Daging Sapi (PSDS) dan upaya penyediaan sapi potong untuk kontinuitas perdagangan sapi potong antar pulau. Penggunaan untuk produksi kambing memang belum berkembang, namun telah dilakukan uji coba baik sebagai suplemen untuk penggemukan maupun sebagai bahan flushing untuk memacu kid crop pada usaha perbibitan kambing.

Berdasarkan uraian di atas, maka materi kegiatan pengabdian kepada masyarakat ini mengambil tema "Penerapan Teknik Flushing Menggunakan Promix Feed Supplement pada Kambing Perbibitan". Tujuannya, adalah: (1)berkembangnya usaha perbibitan kambing PE yang menerapkan teknik flushing di Kabupaten Lombok Utara, (2)meningkatnya kid crop dan efisiensi produksi perbibitan kambing PE yang 
diusahakan para peternak, sehingga diperoleh peningkatan pendapatan yang signifikan, (3)meningkatnya respon apresiatif peternak terhadap penerapan Ipteks dalam usaha perbibitan kambing PE di kabupaten Lombok Utara, NTB.

\section{Khalayak Sasaran}

Kelompok usaha produksi perbibitan kambing PE di kabupaten Lombok Utara berjumlah 56 kelompok, dengan jumlah peternak sekitar 693 orang dan jumlah kambing yang dipelihara sebanyak 7.092 ekor (Zaenuri et al., 2016). Konsentrasi usaha perbibitan kambing PE di Kabupaten Lombok Utara dijumpai tertinggi di Kecamatan Gangga dengan 19 kelompok, 15 kelompok diantaranya tergolong intensif (tatalaksana pemeliharaan kambing PE lebih banyak berlangsung di dalam kandang) dan 4 kelompok lainnya tergolong semi intensif (tatalaksana pemeliharaan dengan kombinasi pengandangan dan pengembalaan); jumlah peternak mencapai 588 orang dengan jumlah kambing PE perbibitan sebanyak 965 ekor (Soekardono et al., 2016).

Berdasarkan gambaran situasi di atas, khalayak sasaran strategis untuk pelaksanaan kegiatan ini diambil dari kelompok-kelompok usaha perbibitan kambing PE di Kecamatan Gangga. Dalam hal ini, dari 15 kelompok usaha perbibitan intensif dan 4 kelompok usaha perbibitan semi-intensif yang ada, ditentukan masing-masing 3 dan 2 kelompok (seluruhnya berjumlah 5 kelompok) yang terbaik berdasarkan kinerja usaha yang ditampilkan menyangkut jumlah anggota (peternak), jumlah kambing PE perbibitan, dan kemampuan produksi (produktivitas). Penentuan masing-masing kelompok sasaran tersebut akan mempertimbangkan juga kelayakan strategis lokasi peternakan (perkandangan) kelompok bersangkutan. Selanjutnya, dari kelima kelompok terpilih ditentukan masing-masing 6 peternak dengan kinerja terbaik sebagai khalayak sasaran antara yang strategis untuk penyebaran inovasi yang dikembangkan. Dengan demikian, jumlah peternak yang dilibatkan sebagai sasaran antara strategis dalam kegiatan ini adalah sebanyak 30 peternak.

\section{Pelaksanaan Kegiatan}

Kegiatan penerapan Ipteks ini dilaksanakan dengan metode demonstrasi plot (demplot), yaitu mendemonstrasikan teknik perbibitan kambing secara pakan kurung dengan aplikasi teknik flushing, pada beberapa kelompok usaha perbibitan kambing di lokasi kegiatan. Demplot yang dilaksanakan disertai dengan kegiatan-kegiatan pelatihan bagi peternak, pendampingan teknis dan manajemen, penyebaran leaflet, serta melakukan monitoring dan evaluasi. Demplot diarahkan pada ternak kambing PE, sedangkan pendampingan dan pelatihan teknis serta penyebaran leaflet diarahkan kepada para peternak, petugas penyuluh pertanian dari dinas/instansi terkait dan tokoh-tokoh masyarakat serta aparat desa setempat yang menunjukkan kesediaan/ketertarikan terhadap materi penerapan Ipteks ini.

Demplot dilakukan dengan mendemonstrasikan teknik perbibitan kambing secara pakan kurung pada 5 kelompok usaha perbibitan kambing di wilayah Kecamatan Gangga Kabupaten Lombok Utara, NTB, melibatkan 50 ekor kambing PE induk 2,0-2,5 tahun milik para peternak pada ke 5 kelompok. Kegiatan ini meliputi: demonstrasi penyiapan kandang perbibitan, demonstrasi pembuatan dan penyajian ransum flushing, dan demonstrasi pengukuran kinerja perbibitan kambing PE.

Sistem perbibitan kambing PE dengan aplikasi teknik flushing, dalam hal ini, merupakan teknik tepat guna yang dapat dikembangkan di kalangan peternakan rakyat, karena teknik ini relatif sederhana yaitu dengan mengurung kambing secara terus menerus disertai pemberian pakan (hijauan + konsentrat) sepenuhnya di dalam kandang selama proses produksi, dan ke dalam pakan yang disediakan ditambahkan agen pemacu superovulasi berupa Promix Feed Supplement (PFS), sesuai hasil penelitian Pribadi et al (2016).

Kambing-kambing demplot dipersiapkan selama 7 hari dengan pemberian ransum basal yang terdiri atas hijauan rumput lapangan dan konsentrat dedak padi. Dalam hal ini, hijauan rumput lapangan yang disediakan secara adlibitum ditimbang terlebih dahulu, sedangkan PFS diberikan sebanyak $0,5 \mathrm{~kg} / \mathrm{ekor} / \mathrm{hari}$ pada pagi hari sebelum kambing mengkonsumsi hijauan. Persiapan ini dimaksudkan untuk mengkondisikan semua Kambing demplot dengan pakan dasar yang disediakan, terutama agar kambing terbiasa dengan konsumsi PFS. Dalam tahap ini, setiap kambing juga diberi obat cacing "Anti Warm" masing-masing 1,5 gram. Semua 
kegiatan dilakukan bersama-sama dengan para peternak dalam rangka transfer inovasi/Ipteks.

Pelatihan dilaksanakan dengan teknik Orasi (ceramah dan diskusi) dan praktik melibatkan para peternak dan peserta lainnya. Dipilih waktu pelaksanaan pada sore hari, yaitu saat para peternak tidak bekerja (setelah selesai menjalankan pekerjaan sehari-hari). Pelaksanaan pelatihan akan mengambil tempat di ruangan atau aula yang ada, menggunakan media LCD. Materi pelatihan disediakan tertulis dalam bentuk leaflet yang dibagikan kepada setiap peserta pelatihan.

\section{Rancangan Evaluasi}

Evaluasi dilakukan dengan maksud untuk mengetahui tingkat pencapaian tujuan kegiatan yang telah dirumuskan. Sehubungan dengan maksud tersebut, pelaksanaan evaluasi diarahkan pada: (1)Perubahan perilaku peternak sasaran (menyangkut peningkatan pengetahuan dan keterampilan dalam tatalaksana perbibitan kambing, serta perubahan pendapatan), (2)Perubahan kinerja perbibitan kambing demplot (menyangkut peningkatan produksi anak, konsumsi pakan, dan efisiensi penggemukan), (3)Respon khalayak sasaran (terutama para peternak dan kelompok-kelompok peternak/usaha perbibitan kambing lainnya di sekitar lokasi demplot) terhadap materi penerapan Ipteks ini.

Untuk mengetahui perubahan perilaku peternak sasaran, dilakukan evaluasi dengan teknik wawancara menggunakan kuesioner. Sedangkan untuk mengetahui perubahan kinerja perbibitan kambing-kambing demplot, dilakukan pengukuran secara langsung terhadap persentase kid crop dan efisiensi reproduksi. Adapun respon khalayak sasaran/kelompok-kelompok usaha perbibitan kambing lainnya di sekitar lokasi kegiatan, dievaluasi dengan teknik observasi langsung terhadap berkembangnya sistem perbibitan kambing secara pakan kurung dengan aplikasi teknik flushing.

\section{Hasil dan Pembahasan}

\section{Pencapaian Tujuan}

Pencapaian tujuan kegiatan penerapan Ipteks pada Kelompok Peternak Kambing Perbibitan di Desa Ganggelang dan Desa Rempek Kecamatan Gangga Kabupaten Lombok Utara, dapat dilihat dari hasil evaluasi yang menunjukkan, semua peternak sasaran kegiatan (100\%) menunjukkan respon positif terhadap semua rangkaian Ipteks yang diterapkan, dalam hal ini, $80 \%$ peserta telah memahami dengan baik pengetahuan praktis yang disampaikan penyuluh, dan $20 \%$ sisanya tampak hanya memahami bagian materi yang didemonstrasikan penyuluh saja. Dengan demikian, dapat dikatakan bahwa tujuan umum kegiatan ini untuk meningkatkan pengetahuan dan keterampilan peternak mengenai penerapan teknik flushing untuk memacu produksi kambing perbibitan yang efektif dan efisien, telah tercapai dengan baik.

Kegiatan pengabdian kepada masyarakat ini, juga telah dapat mengatasi permasalahanpermasalahan khusus yang dihadapi peternak dalam usaha kambing perbibitan seperti: kid crop (jumlah anak kambing yang dihasilkan) yang masih rendah sebagaimana teridentifikasi dari masih rendahnya angka kelahiran kembar pada induk kambing yang diusahakan, kidding interval (interval kelahiran anak) yang panjang menyebabkan menjadi rendahnya efisiensi reproduksi ternak, mortalitas neonatal (kematian anak yang baru lahir) sering terjadi akibat kurang baiknya penanganan kondisi neonatal, laju pertumbuhan kambing lepas sapih tergolong rendah sehingga lama waktu untuk pemeliharaan anak kambing hingga dicapainya performa standar untuk kambing bibit/bakalan menjadi relatif panjang, dan kualitas performa kambing bibit/bakalan yang dihasilkan kurang memadai, minimnya upaya recording dalam pelaksanaan usaha produksi, sehingga proses produksi menjadi kurang terkontrol dan tidak efisien.

Adapun hasil yang dicapai sehubungan dengan penerapan teknik flushing pada kambingkambing induk, adalah:

1) Semua kambing induk (100\%) melahirkan cempe kembar, dengan rincian persentase melahirkan kembar-2, kembar-3, dan kembar-4 berturut-turut 20,65 , dan $15 \%$, sehingga kid crop meningkat dari 30 menjadi 59 ekor untuk 20 ekor induk, sehingga setiap induk dapat beranak rata-rata 2,95 (= 3 ekor) dalam 1 kali beranak. Angka litter size rata-rata 3 ekor per kelahiran ini lebih tinggi dibanding litter size kambing PE menurut Devendra dan Burns (1994) sebesar 1,5 per kelahiran, juga lebih tinggi dibanding litter size kambing silangan Boer $\mathrm{x}$ PE yang dilaporkan Kaunang et al 
(2013) sebesar rata-rata 1,8. Hal ini menunjukkan, teknik flushing menggunakan Promix Feed Supplement (PFS) yang diterapkan dalam demplot ini sangat efektif dalam memacu kinerja sifat prolific kambingkambing induk dalam demplot

2) Berat badan (lahir, sapih, maupun lepas sapih) cempe yang dihasilkan, demikian juga laju pertumbuhan cempe pra maupun lepas sapih meningkat sehingga lama waktu untuk pemeliharaan anak kambing hingga dicapainya performa standar untuk kambing bibit/bakalan menjadi lebih singkat, dan kualitas performa kambing bibit/bakalan yang dihasilkan cukup memadai. Demikian juga berdasarkan performa yang diukur secara langsung dari parameter panjang badan, tinggi badan, dan lingkar dada cempe saat baru lahir, fase pra sapih maupun lepas sapih, dapat dinyatakan bahwa cempe yang dihasilkan oleh kambing-kambing induk dalam demplot ini memiliki kualitas performa yang lebih tinggi dibanding cempe dari kambing-kambing induk non demplot.

3) Kejadian mortalitas neonatal (kematian anak yang baru lahir) dapat diminimalisir, ditemukan hanya $1(1,9 \%)$ kasus yaitu pada cempe yang lahir kembar 4. Angka ini jauh lebih rendah dibanding angka mortalitas neonatal kambing Silangan Boer $x$ PE rata-rata $10,7 \%$ sebagaimana dilaporkan Kaunang et al (2013), juga lebih rendah dibanding mortalitas pra sapih kambing Silangan Boer $x$ Kacang menurut laporan Nurgiatiningsih (2016) berkisar 10-15\%. Sebagai gambaran mengenai kondisi fisiologis cempe neonatal atau dałam fase prasapih, Wodzica-Tomaszewska et al (1993) menjelaskan, pada kambing fase pra sapih dapat dikatakan merupakan periode kritis, karena pada fase pra sapih, anak belum mampu secara aktif membentuk antibodi untuk melindungi dirinya. Satu-satunya jalan ialah secara pasif dan kolostrum. Menurut pengalaman dan hasil dari penelitian-penelitian, ternyata memang pada periode lahir sampai sapih merupakan saat dengan angka kematian anak dan induk yang tertinggi.

4) Pelaksanaan recording dalam pelaksanaan usaha produksi berjalan cukup baik, sehingga proses produksi menjadi terkontrol dan efisien.

\section{Pencapaian Manfaat}

Ipteks yang diterapkan, sebagaimana hasil evaluasi yang dilakukan, tampak sangat membantu para peternak dalam mengatasi permasalahan inefisiensi usaha perbibitan kambing yang dihadapi selama ini, karena penerapan inovasi tersebut ternyata dapat meningkatkan efisiensi reproduksi dan kualitas produksi kambing bibit yang dihasilkan. Dengan peningkatan kuantitas dan kualitas kambing bibit yang dicapai, para peternak dapat meningkat pendapatannya hingga sekitar $47 \%$ terhadap pendapatan dari usaha perbibitan kambing yang dijalankan sebelumnya.

Disamping manfaat yang diperoleh langsung oleh para peternak, kegiatan ini juga tampak bermanfaat terhadap berkembangnya sistem perbibitan kambing dengan penerapan IPTEKS di kalangan kelompok usaha perbibitan kambing setempat. Perkembangan ini secara tidak langsung akan memberi manfaat pula dalam membantu upaya perbaikan tatalaksana perbibitan kambing berbasis Ipteks yang tengah digalakkan pemerintah, dalam rangka swasembada nasional protein hewani.

\section{Faktor Pendorong dan Penghambat}

Beberapa faktor yang menjadi pendorong terlaksananya kegiatan Pengabdian kepada Masyarakat ini, adalah: 1) Program pemerintah dalam bidang peternakan, yang, salah satu diantaranya adalah Program Swasembada Protein Hewani (PSPH), yang ditargetkan tercapai pada 2025, 2) Peran aparat pemerintah setempat, terutama kepala desa beserta perangkatnya, yang sangat antusias dalam mendukung lancarnya pelaksanaan kegiatan ini, 3) Dukungan masyarakat, terutama para tokoh dan pemuka masyarakat setempat, berupa berbagai masukan sebagai bahan kajian dan pertimbangan bagi tim penyuluh, dukungan tenaga dan tempat, juga berupa peran serta dalam pengerahan massa, 4) Adanya kesadaran para peternak terhadap pentingnya ilmu pengetahuan dan teknologi dalam rangka meningkatkan keterampilan dan hasil beternak mereka. Hal ini cukup membantu dalam menghadirkan mereka untuk mengikuti kegiatan ini, dan yang terpenting adalah motivasi mereka untuk mengikuti kegiatan ini didasari oleh kebutuhan mereka terhadap pengetahuan dan teknologi, 5) Adanya kelembagaan petani/peternak, antara lain kelompok-kelompok peternak kambing, keberadaannya sangat potensial sebagai media 
penyebaran informasi inovatif dalam masyarakat. Kelembagaan yang ada, juga dapat menjadi sasaran strategis kegiatan pengabdian kepada masyarakat, 6) Adanya balai atau berugak di sekitar kandang lokasi kegiatan, dapat menjadi tempat berkumpul para peternak untuk membahas/mengembangkan informasi inovatif yang disuluhkan.

Adapun beberapa faktor yang dipandang sebagai penghambat kelancaran pelaksanaan kegiatan pengabdian pada masyarakat ini, adalah: 1) Rendahnya tingkat pendidikan rata-rata peternak peserta penyuluhan yang menjadi sasaran langsung kegiatan. Sebagian besar petani/peternak tersebut (48\%) hanya berpendidikan SD bahkan terdapat 5\% lainnya tidak berpendidikan dan tidak mampu baca tulis, 28\% berpendidikan SLTP dan hanya 19\% berpendidikan SLTA. Hal ini menghambat proses adopsi pengetahuan dan teknologi yang disuluhkan, 2) Tidak tersedianya sarana listrik yang memadai di lokasi kegiatan, hal ini menghambat/membatasi tim penyuluh untuk menggunakan peralatan pendukung seperti LCD, 3) Kesempatan yang dimiliki tiap petani/peternak untuk mengikuti kegiatan ini tidak sama dan terbatas. Karena itu, waktu dan durasi pelaksanaan kegiatan ini menjadi sangat terbatas dan tidak optimum karena terpaksa mesti disesuaikan dengan keterbatasan kesempatan tersebut, 4) Masyarakat pada umumnya di lokasi kegiatan ini tampak telah terkondisi dengan proyekproyek pemberian bantuan sosial (bantuan material), sehingga kehadiran Tim Pengabdian kepada Masyarakat di desa diasosiasikan dengan tim dari proyek sejenis yang datang membawa atau menjanjikan bantuan material.

\section{Kesimpulan}

Berdasarkan hasil evaluasi terhadap pencapaian tujuan dan manfaat kegiatan yang dilaksanakan dalam pengabdian kepada masyarakat ini dapat dikemukakan disimpulkan sebagai berikut:

1) Upaya peningkatan produktivitas peternakan kambing perbibitan di Kabupaten Lombok Utara dapat ditempuh melalui transfer IPTEKS kepada para peternak dengan melaksanakan demonstrasi plot (demplot) penerapan teknik Flushing secara on farm

2) Adapun pencapaian manfaat kegiatan yang dievaluasi dengan pengukuran langsung terhadap performa perbibitan yang meliputi parameter-parameter reproduktif maupun produktif kambing demplot menunjukkan, bahwa penerapan teknik Flushing sangat bermanfaat dalam mengatasi rendahnya angka kid crop sebagai akibat rendahnya performa prolifikasi ternak kambing perbibitan yang dibudidayakan.

\section{Ucapan Terima Kasih}

Secara khusus, Tim Penyuluh menyampaikan terimakasih dan penghargaan kepada Wakil Bupati KLU (Dani Febrianto Ridawan, ST., M.Eng) atas dukungan fasilitas dan penyediaan data/informasi yang sangat mencukupi selama kegiatan berlangsung, dan kepada segenap aparatur Pemda KLU atas kerjasama dalam pembinaan kelompok-kelompok peternak sasaran melalui kegiatan ini.

\section{Daftar Pustaka}

Blakely, J. dan D.H. Bade, 1991. The Science of Animal Husbandry. $\quad 4^{\text {th }}$ Ed. Printic-Hall Inc. New Jersey

Devendra, C. dan M. Burns, 1994. Produksi Kambing di Daerah Tropis. Penerbit ITB, Bandung

Kaunang, D., S. Suyadi, dan S. Wahjuningsih, 2013. Analisis Litter Size, Bobot Lahir, dan Bobot Sapih Hasil Perkawinan Alami dan Inseminasi Buatan Kambing Boer dan Peranakan Etawa (PE). J. Ilmu-Ilmu Peternakan 23(3):41-46

Nasich, M., 2011. Produktivitas Kambing Hasil Persilangan antara Pejantan Boer dengan Induk Lokal (PE) Periode Pra Sapih. J. Ternak Tropika, 12(1):56-62

Nurgiatiningsih, V.M.A., 2016. Evaluasi Genetik Kambing Boer Berdasarkan Performan Hasil Persilangannya dengan Kambing Lokal. J. Ternak Tropika, 17(1):82-88

Pribadi, L.W. dan R. Rodiah, 2011. Promosi Kinerja Kambing PE sebagai Kambing Potong Unggul dengan Introduksi Genetik Kambing Boer. ORYZA, 10(2):11-21

Rozani, M. K., Agustin, N., Adhani, Y., Agustini, H., \& Syukur, A. (2021). Optimalisasi Hasil Produksi Susu Kambing Peranakan Etawa Melalui Ekonomi Kratif Berbasis Mitra Untuk Mendukung Pariwasata. Jurnal Pengabdian Magister Pendidikan IPA, 4(2). 
Wodzika-Tomaszweska, M., I.M. Mastika, A. Jayanegara, S. Gardiner, dan T.R. Wiradarya, 1993. Produksi Kambing dan Domba di Indonesia. Sebelas Maret Univ. Press. Surakarta

Yamin, M., Khairuddin, K., Artayasa, P., Sahidu, K., \& Darmansyah, D. (2021). Pemberdayaan Masyarakat Melalui Pelatihan Teknis Beternak Kambing di Desa Gunungsari Kabupaten Lombok Barat. Jurnal Pengabdian Magister Pendidikan IPA, 4(3).

Zaenuri, L.A., Lukman HY, dan I W.L. Sumadiasa, 2008. Kinerja Produksi dan Reproduksi Kambing Lokal yang Disilangkan dengan Kambing Boer. J. Ilmu dan Teknologi Peternakan (JITP), 4:226-223. 